\title{
The Influence of the Syrup Type on Rheology, Color Differences, Water Activity, and Nutritional and Sensory Aspects of High-Protein Bars for Sportsmen
}

\author{
Jan Małecki $\mathbb{D}^{1,2}{ }^{1,2}$ Igor Tomasevic $\mathbb{D}^{3},{ }^{3}$ and Bartosz G. Sołowiej $\mathbb{B D}^{1}$ \\ ${ }^{1}$ Department of Dairy Technology and Functional Foods, Faculty of Food Sciences and Biotechnology, \\ University of Life Sciences in Lublin, Skromna 8, Lublin 20-704, Poland \\ ${ }^{2}$ EUROHANSA Sp. $z$ o.o., ul. Letnia 10-14, 87-100 Toruń, Poland \\ ${ }^{3}$ Department of Animal Source Food Technology, Faculty of Agriculture, University of Belgrade, Nemanjina 6, \\ Belgrade 11080, Serbia \\ Correspondence should be addressed to Bartosz G. Sołowiej; bartosz.solowiej@up.lublin.pl
}

Received 21 November 2021; Revised 1 January 2022; Accepted 8 January 2022; Published 30 January 2022

Academic Editor: Alessandro Di Cerbo

Copyright (C) 2022 Jan Małecki et al. This is an open access article distributed under the Creative Commons Attribution License, which permits unrestricted use, distribution, and reproduction in any medium, provided the original work is properly cited.

\begin{abstract}
Most often, high-protein bars consist of a protein preparation in the form of a loose powder, stuck together with a syrup mixture, ensuring a stable mass. According to the legal regulations in force, at least $20 \%$ of the energy value must come from protein for the product to be called high-protein. The objective of this study was to evaluate the impact of different syrup sources (oligofructose, maltitol, tapioca fiber, and chickpea-maize fiber) on rheology, water activity, color, and nutritional and sensorial properties of high-protein bars. Texture has changed depending on the type of syrup used. A significant increase of the hardness parameter referring to the control sample was noted for bars containing chickpea-maize liquid fiber in chocolate $(311.65 \mathrm{~N})$, with low adhesiveness simultaneously $(54.71 \mathrm{~N})$. Samples without chocolate made with the use of oligofructose syrup had apparently higher dynamic viscosities than other bars $\left(226.67 \mathrm{mPas} \cdot \mathrm{g} / \mathrm{cm}^{3}\right)$. The water activity of all tested bars indicated the high stability of samples over time $(<0.80)$, except for samples without chocolate made of PM syrup. The color of the tested bars was from light cream to Earth yellow. Bars obtained with tapioca liquid fiber had the lowest nutritional value. Results presented in this study suggest that selecting the correct type of syrup may significantly influence the functional properties of high-protein bars.
\end{abstract}

\section{Introduction}

High-protein bars have been a growing industry over the last few years [1]. Because of this growth, manufacturers are preparing new formulations to meet consumer needs, first of all, with a reduced tendency to harden during storage. However, on the EU market, the vast majority of high-protein products are still made with high-sugar, glucose-fructose, and glucose syrups due to the excellent technological properties of these syrups. The addition or substitution of different ingredients like protein, syrup, fat, sweetener, and inclusions can potentially increase the chance of manufacturing issues [2].

The food industry has developed many new high-protein bar recipes to keep current with consumer preferences and expectations. Unfortunately, due to the low cost of standard raw materials (high-fructose syrups and sugar syrups), most producers do not decide to modify these elements in their recipes, especially when it comes to syrups. High-protein bar formulations consist of three common ingredients: protein powder, syrup, and some form of fat [3]. First, these ingredients conditioned the creation of the correct features of a high-protein product from production (features determining technological suitability allowing for high production efficiency) until the product hits the store shelf and the final consumer. Therefore, it seems appropriate to search for suitable alternatives to commonly used ingredients such as high-fructose and glucose syrups, fats, or allergenic proteins, into their alternative components, e.g., polyols, fructooligosaccharides, or different protein sources (plant and animal 
proteins), while maximizing maintaining the technological parameters of the production process [4].

Food research is constantly searching for new ways to replace sugar. It is due to the negative connotations of sugar consumption on health, which has driven consumer demand for healthier products and is reflected on a national level by taxation, especially sugary beverages. Sugar alcohols, a class of polyols, are present at varying levels in many fruits and vegetables and can be added to foods such as low calorific sweeteners. The most commonly used polyols in food include sorbitol, mannitol, xylitol, erythritol, maltitol, lactitol, and isomalt. Products resulting from such activities can be of particular interest to people using different diets [5]. It is worth noting that obesity has increased dramatically in recent decades, a phenomenon widely associated with the so-called "western diet": energy-dense, highly palatable foods with high fat and sugar content. Dietary fiber consists of nondigestible forms of carbohydrate, usually polysaccharides, which originate from plant-based foods. Over recent decades, our diet within Westernized societies has changed radically from our hominid ancestors, with implications for our coevolved gut microbiota. It includes increased ingestion of ultraprocessed foods that are typically impoverished of dietary fiber and associated reduction in the intake of fiber-replete plant-based foods. Over recent decades, there has been a transformation in our understanding of the health benefits of dietary fiber [6]. Based on observation of most commercial high-protein bar labels, there is a low variety of each basic ingredient used; for simplicity, this study used a model system composed of glucose syrup (GS), whey protein concentrate (WPC), and liquid vegetable fat, that is, rapeseed oil. In general, the level of each ingredient likely impacts the mechanical behaviors, textures, and nutritional value of high-protein bars [7].

According to our current available knowledge, there is no research on ultrasonic viscosity and determining the color differences by Computer Vision System (CVS), and no such studies are using industrial devices, which ensure high repeatability of the parameters of the final products for the application of high-protein bars. Furthermore, the use of alternative syrup sources, e.g., chickpea-maize fiber, oligofructose, and tapioca in the production of high-protein bars, is limited. The research was aimed at determining whether the replacement of the type of syrup (oligofructose, maltitol, tapioca fiber, chickpea, and corn fiber) will have an impact on the texture, rheology, water activity, differences in color, and nutritional and sensory properties of high-protein bars and their possible declarations in accordance with applicable European Union (EU) legislation.

\section{Materials and Methods}

2.1. Materials. The following raw materials were used to prepare high-protein bars: glucose syrup (GS-Dextrose Equivalent "DE" 40, Amylon, Havlíčkův Brod, Czech Republic), maltitol syrup (ML - 50-55\% maltitol, Roquette, Lestrem, France), oligofructose syrup from chicory inulin (OF-oligofructose content $\geq 73 \%$, Sensus, Roosendaal, Netherlands), tapioca liquid fiber (TF-dry substances $\geq 75 \%$, K2B, Searles Meadow, Cambridge, United Kingdom), chickpea-maize liquid fiber (PM-dry substances $\geq 74 \%$, HiFood, Parma, Italy), whey protein concentrate (WPC80, $80 \%$ proteins, Polser Sp. z o. o., Toruń, Poland), maltodextrin (Dextrose Equivalent "DE” 15, Amylon, Havlíčkův Brod, Czech Republic), vegetable oil (rapeseed oil) (ZT "Kruszwica" S.A., Kruszwica, Poland), soy lecithin (Identity Preserved "IP" 50, Brenntag, Kędzierzyn-Koźle, Poland), powdered barley malt extract (Mountons Ingredients, European Brewery Convention "EBC" color: 5 to 12), chocolate (Barry Callebaut, Łódź, Poland), and natural vanilla aroma in powder (GBD Aromaty, Warsaw, Poland).

2.2. Preparation of High-Protein Bars. The first step was to mix protein concentrate $(38.18 \%, \mathrm{w} / \mathrm{w})$ with aroma $(0.91 \%, \mathrm{w} /$ $\mathrm{w})$ and maltodextrin $(5.45 \%, \mathrm{w} / \mathrm{w})$ using the B10A industrial mixer (Technologies 4ALL Sp. z o. o. Sp. k.; Kępno, Poland) at $190 \mathrm{rpm}$ for $1 \mathrm{~min}$. In a separate laboratory vessel, barley malt extract $(3.64 \%, \mathrm{w} / \mathrm{w})$ was dissolved in water $(5.45 \%, \mathrm{w} / \mathrm{w})$. Soy lecithin $(0.91 \%, \mathrm{w} / \mathrm{w})$ and rapeseed oil $(13.64 \%, \mathrm{w} / \mathrm{w})$ were mixed in the second vessel. Syrups $(31.82 \%$, w/w) were heated to $80^{\circ} \mathrm{C}$ and then combined with dry ingredients. The remaining ingredients prepared earlier were added to the mixer bowl simultaneously after pouring the syrup. The prepared mass was mixed for $5 \mathrm{~min}$ at $365 \mathrm{rpm}$ using an oar end. In the end, processed high-protein bar mass was laid onto the conveyor belt using the CONBAR 600 (SOLLICH $\mathrm{GmbH} \& \mathrm{Co}$. KG, Bad Salzuflen, Germany) and pulled out by forming rollers to a height of $15 \mathrm{~mm}$ and then cooled to $10^{\circ} \mathrm{C}$ for $15 \mathrm{~min}$ using the cooling tunnel. The chilled bar mass was subjected to longitudinal cutting using the longitudinal slitter. Finally, the longitudinally cut mass was cut transversely using the CONBAR 600 transverse guillotine into individual bars $(95 \times 30 \mathrm{~mm})$. The bars to be coated with chocolate were covered with chocolate (22\%, w/w) using the DK3520 (A.E. NIELSEN Maskinfabrik ApS., Farum, Denmark). Chocolate had a temper index (TI) oscillating in the range of 5.0-5.5, measured using the Temper meter RET-250TMK (ELMI Automatic Systems, Warsaw, Poland). Next, chocolate-coated bars were cooled using the DK3520 A.E. NIELSEN cooling tunnel to a temperature of $10^{\circ} \mathrm{C}$ for $15 \mathrm{~min}$. The prepared bars were packed in high-barrier foil using a manual impulse sealer PFS 200 (NOVUMPACK, Kraków, Poland). After the storage period (room temperature, plastic container), the samples were tested. The high-protein bar samples were unpacked from the foil $5 \mathrm{~min}$ before measurements. Cylindrical blocks in height of $15 \mathrm{~mm}$ and diameter of $12 \mathrm{~mm}$ were punched out to analyze the texture of tested bars. The sample was prepared alike by weighing $6 \mathrm{~g}$ of sample for testing to determine viscosity and water activity. Each high-protein bar sample was prepared in twenty repetitions.

The recipe was developed on the basis of products available on the market, our experience and knowledge of current market trends, and a previous publication [4]. Before that, an optimization of different ingredients was performed.

2.3. Texture Profile Analysis (TPA). Hardness, adhesiveness, fracturability, and cohesiveness were evaluated using the TA-XT2i Texture Analyzer (Stable Micro Systems, 
Godalming, Surrey, UK). All measurements were performed, following the protocol defined by Małecki et al. [4]. The samples were pressed twice by a probe with a diameter of $36 \mathrm{~mm}$ (SMS P/36R) until deformation of $70 \%$ was obtained (load cell $50 \mathrm{~kg}$, the speed rate of the probe was $1 \mathrm{~mm} / \mathrm{s}$, interval between probe movements: $5 \mathrm{~s}$ ). Analyses were carried out in five replications for each sample.

2.4. Cutting Test. According to the method of Małecki et al. [4], the cutting strength of high-protein bars was measured using TA-XT2i Texture Analyzer (Stable Micro Systems, Godalming, Surrey, UK). The blade set with a knife (HDP/ BSK) comprising a Warner Bratzler blade (a reversible blade with knife edge) with a slotted blade insert and a blade holder was used for the experiment. The samples were placed on a metal plate. The used blade was lowered at a speed of $2 \mathrm{~mm} / \mathrm{s}$. Five repetitions were applied for each formulation.

2.5. Viscoelastic Properties. The Kinexus lab + rheometer (Malvern Panalytical, Cambridge, UK) with serrated plates (PU40 SR3012 SS and PLS40 S2339 SS, at the plate-plate configuration) was used to evaluate storage $\left(G^{\prime}\right)$, loss $\left(G^{\prime \prime}\right)$ moduli, and phase angle $(\delta)$ of high-protein bars. Measurements were made at $21^{\circ} \mathrm{C}$ and frequency of $0.1 \mathrm{~Hz}$ and computer-registered in the Kinexus Malvern program-rSpace.

2.6. Back Extrusion. The TA-XT2i Texture Analyzer (Stable Micro Systems, Godalming, Surrey, UK) was used with a back extrusion test to measure the consistency of syrups used to obtain bars. A back extrusion ring was used with a container diameter of $50 \mathrm{~mm}$ and a head diameter of $45 \mathrm{~mm}$. Head travel speed was $1 \mathrm{~mm} / \mathrm{s}$. Measurements were performed in three replications.

2.7. Water Activity. According to Szafrańska et al. [8], measurements were performed at the temperature of $25^{\circ} \mathrm{C}$, in five repetitions using the AWMD-10 water activity meter (NAGY, Gäufelden, Germany). Water activity $\left(a_{\mathrm{w}}\right)$ was measured with an accuracy of \pm 0.001 of the $a_{\mathrm{w}}$ unit.

\subsection{Computer Vision System (CVS) and Determining Color} Differences. Color differences were determined using Computer Vision System (CVS), according to Tomasevic et al. [9]. Colorimetric measurements (three repetitions) of obtained products was expressed in terms of the International Commission on Illumination (CIE $L^{*} a^{*} b^{*}$ ) color space with the coordinates being $a^{*}$ (red-green), $b^{*}$ (yellowblue), and $L^{*}$ (0-100, estimation of lightness) [10]. According to the NBS (National Bureau of Standard) reference scale, the notable differences could be described as "marked changes", implying that such changes are perceptible to the human eye. A bar made of GS syrup was adopted as a control sample.

The total color difference was calculated using the following formula:

$$
\Delta E=\sqrt{\left(a_{1}-a_{2}\right)^{2}+\left(b_{1}-b_{2}\right)^{2}+\left(L_{1}-L_{2}\right)^{2}} .
$$

The $\Delta E^{*}$ values were converted into National Bureau of Standards (NBS) units by equation (11):

$$
\text { NBS units }=\Delta E \times 0.92 \text {. }
$$

2.9. Ultrasonic Viscosity. The ultrasonic viscometer Unipan type 505 (UNIPAN, Warsaw, Poland) was applied to evaluate the dynamic viscosity of bars according to the method of Małecki et al. [4]. Viscosity tests using ultrasonic signals involve the use of a probe that generates free vibrations. The alternating electric current induces an alternating magnetic field, which deforms ferromagnetic materials (magnetostriction). The generated waves are damped by the tested material. Measurements of the viscosity were performed at $25^{\circ} \mathrm{C}$. The results were read in $\mathrm{mPas} \cdot \mathrm{g} / \mathrm{cm}^{3}$. All measurements were performed in three repetitions.

2.10. Nutritional Value. Nutritional value was calculated using the X-mart (X-mart Group Sp. z o. o., Lublin, Poland) software based on raw material specifications obtained from suppliers of each ingredient. Data was introduced into the program, and the nutritional value of the finished product was calculated per $100 \mathrm{~g}$.

2.11. Sensory Evaluation. Fifteen trained consumers took part in sensory evaluation. They were recruited from EUROHANSA Sp. z o. o. (Puławy, Poland). The criteria used in panelists selection are as follows: age between 18 and 60 years old, regular consumers of high-protein bars, and not allergic to any raw material used. Panelists were instructed to evaluate the sensory attributes: aroma, color, taste, and consistency. A 5-point scale was used to describe each product (from 1 =extremely dislike to $5=$ extremely like) based on the Quantitative Descriptive Analysis (QDA) method with significance factors (0.2-aroma, 0.2-color, 0.35 -taste, and 0.25 -consistency) $[12,13]$.

2.12. Statistical Analysis. Statistical analysis was carried out using STATISTICA 13.3 PL software (Dell Software Inc., Round Rock, USA). A one-way ANOVA analysis was applied. Significant differences between high-protein bars were determined by the Tukey post hoc test at $P<0.05$.

\section{Results and Discussion}

3.1. Texture Profile Analysis (TPA) and Cutting Test. The impact of various syrups on the hardness, fracturability, cohesiveness, adhesiveness, and cutting resistance of the acquired prepared high-protein bars with or without chocolate covering is introduced in Tables 1 and 2. Huge contrasts $(P<0.05)$ were noticed. The bars made of glucose syrup (GS) and chickpea-maze syrup (PM) had the most elevated hardness (91.43 N-GS and 81.97 N-PM for bars without chocolate and $311.65 \mathrm{~N}-\mathrm{PM}$ and $106.26 \mathrm{~N}-\mathrm{GS}$ for 
TABLE 1: Impact of different syrup applications on high-protein bars texture attributes and cutting resistance.

\begin{tabular}{lccccc}
\hline \multirow{2}{*}{$\begin{array}{l}\text { Type of syrup used in bars without } \\
\text { chocolate covering }\end{array}$} & Hardness $(\mathrm{N})$ & $\begin{array}{c}\text { Texture attributes } \\
\text { Fracturability } \\
\end{array}$ & $\begin{array}{c}\text { Adhesiveness } \\
(\mathrm{N})\end{array}$ & $\begin{array}{c}\text { Cohesiveness } \\
\text { Cutting resistance force } \\
(\mathrm{N})\end{array}$ \\
\hline OF & $26.75^{\mathrm{a}} \pm 0.893$ & $0.13^{\mathrm{b}} \pm 0.017$ & $13.47^{\mathrm{c}} \pm 1.320$ & $0.34^{\mathrm{bc}} \pm 0.009$ & $133.25^{\mathrm{a}} \pm 3.622$ \\
TF & $53.06^{\mathrm{b}} \pm 1.981$ & $0.21^{\mathrm{d}} \pm 0.011$ & $16.13^{\mathrm{d}} \pm 2.000$ & $0.34^{\mathrm{bc}} \pm 0.015$ & $163.25^{\mathrm{c}} \pm 3.999$ \\
ML & $62.44^{\mathrm{c}} \pm 0.692$ & $0.20^{\mathrm{cd}} \pm 0.007$ & $28.22^{\mathrm{e}} \pm 1.518$ & $0.36^{\mathrm{c}} \pm 0.020$ & $167.56^{\mathrm{c}} \pm 1.337$ \\
PM & $81.97^{\mathrm{d}} \pm 1.261$ & $0.19^{\mathrm{c}} \pm 0.009$ & $3.01^{\mathrm{a}} \pm 0.446$ & $0.17^{\mathrm{a}} \pm 0.005$ & $135.49^{\mathrm{a}} \pm 2.808$ \\
GS & $91.43^{\mathrm{e}} \pm 0.250$ & $0.04^{\mathrm{a}} \pm 0.002$ & $8.68^{\mathrm{b}} \pm 0.299$ & $0.32^{\mathrm{b}} \pm 0.017$ & $156.16^{\mathrm{b}} \pm 2.947$ \\
\hline
\end{tabular}

Data are presented as means \pm SD (standard deviation). ${ }^{a-e}$ Means in the same column with different superscripts are significantly different $(P<0.05$, Tukey's honestly significant difference "HSD" test). OF: oligofructose, TF: tapioca liquid fiber, ML: maltitol, and PM: chickpea-maize liquid fiber.

TABLE 2: Impact of different syrup applications on high-protein bars texture attributes and cutting resistance.

\begin{tabular}{|c|c|c|c|c|c|}
\hline \multirow[b]{2}{*}{$\begin{array}{l}\text { Type of syrup used in bars with chocolate } \\
\text { covering }\end{array}$} & \multicolumn{4}{|c|}{ Texture attributes } & \multirow[b]{2}{*}{$\begin{array}{l}\text { Cutting resistance force } \\
\qquad(\mathrm{N})\end{array}$} \\
\hline & $\begin{array}{l}\text { Hardness } \\
\quad(\mathrm{N})\end{array}$ & $\begin{array}{l}\text { Fracturability } \\
\qquad(\mathrm{N})\end{array}$ & $\begin{array}{l}\text { Adhesiveness } \\
(\mathrm{J})\end{array}$ & Cohesiveness & \\
\hline OF & $38.79^{\mathrm{a}} \pm 0.432$ & $0.10^{\mathrm{cb}} \pm 0.013$ & $\begin{array}{c}145.32 \\
\mathrm{~b} \pm 15.302\end{array}$ & $0.27^{\mathrm{b}} \pm 0.010$ & $70.10^{\mathrm{a}} \pm 0.803$ \\
\hline $\mathrm{TF}$ & $81.61^{\mathrm{b}} \pm 1.167$ & $0.12^{c} \pm 0.011$ & $\begin{array}{c}214.53 \\
{ }^{c} \pm 14.285\end{array}$ & $0.23^{\mathrm{a}} \pm 0.015$ & $124.95^{\mathrm{b}} \pm 0.566$ \\
\hline ML & $73.36^{b} \pm 0.672$ & $0.09^{b} \pm 0.007$ & $\begin{array}{l}236.99 \\
{ }^{c} \pm 24.602\end{array}$ & $0.30^{b} \pm 0.009$ & $132.01^{\mathrm{c}} \pm 2.145$ \\
\hline $\mathrm{PM}$ & $\begin{array}{c}311.65 \\
\mathrm{~d}_{ \pm} \pm 10.401\end{array}$ & $0.12^{\mathrm{c}} \pm 0.012$ & $54.71^{\mathrm{a}} \pm 3.596$ & $0.28^{b} \pm 0.013$ & $124.12^{\mathrm{b}} \pm 0.928$ \\
\hline GS & $\begin{array}{c}106.26 \\
{ }^{c} \pm 2.149\end{array}$ & $0.04^{\mathrm{a}} \pm 0.009$ & $\begin{array}{c}571.75 \\
\mathrm{~d} \\
\pm 23.101\end{array}$ & $0.34^{c} \pm 0.033$ & $148.68^{\mathrm{d}} \pm 4.688$ \\
\hline
\end{tabular}

Data are presented as means \pm SD (standard deviation). ${ }^{\text {a-d }}$ Means in the same column with different superscripts are significantly different $(P<0.05$, Tukey's HSD test). OF: oligofructose, TF: tapioca liquid fiber, ML: maltitol, and PM: chickpea-maize liquid fiber.

bars with chocolate covering). In correlation, the most reduced hardness described bars were produced using oligofructose $(\mathrm{OF})$ in both the examples without chocolate $(26.75 \mathrm{~N})$ and with the chocolate covering $(38.79 \mathrm{~N})$.

A possible way to explain the tendency to harden highprotein bars may also be the phenomenon of dissolving some proteins during the mixing of ingredients and then precipitation of proteins for the next few days from the production of the final products. It can cause the extraction of water from the product and dissolved protein, which is related to the competition for hydration water between dissolved and undissolved proteins [14]. By and large, the hardness of high-protein bars is generally high and increases with the expansion of protein [15]. A wide variety of parameters characterized the developed high-protein bars. Considering the examination of Małecki et al. [4] and Mcmahon et al. [16], some routineness can be seen for bars made of whey proteins, glucose syrup, or high-fructose corn syrups. A high worth of the hardness goes with bars made of this kind of protein and syrups. A relatively low value of the hardness parameter translates into low adhesiveness values in bars without chocolate and higher levels of this parameter in chocolate-coated bars. The different situations can be seen for PM syrup. Despite the high hardness of the bar made of this type of syrup, it correlates with low adhesiveness values in both samples (with and without chocolate). The results obtained from the research on a bar made of PM syrup also deserve attention due to the relatively low level of all TPA parameters, particularly in the sample without chocolate covering. The obtained results also confirm the research carried out earlier by McMahon et al. [16] in which the use of polyhydric alcohols such as sorbitol or maltitol reduces the hardness of high-protein bars during the storage process compared to products made on glucose syrups and highfructose corn syrups.

Regarding Tables 1 and 2, the bars made of ML and TF without chocolate (167.56 N-ML; $163.25 \mathrm{~N}-\mathrm{PM})$ and GS with the chocolate covering $(148.68 \mathrm{~N})$ showed the most considerable cutting opposition. Then, again, the most minor cutting opposition characterized a high-protein bar made with OF syrup without chocolate $(70.10 \mathrm{~N})$. The acquired outcomes correspond with the cohesiveness examination and affirm the connection between the cohesiveness of bars and the power expected to cut them. As a general rule, it very well may be seen that the chocolate-covered bars had higher protection from the cutting power. Cutting resistance differences for bars bade of GS, ML, TF, and PM are significant but not very large. This occurrence may result from the degree of chocolate tempering, which slightly changes during the chocolate tempering process. Chocolate with a temper index (TI) level of 5.0-5.5 is described as high hardness, causing a snap when breaking, which is an element wanted by buyers in this kind of item. It is likewise affirmed by the sensory examination performed. The deviations 
might be identified with the adhesiveness of the chocolate layer in some places of the bars because under conditions, the products are covered with a surge of chocolate, and too high layer of chocolate is brushed off through an impact of packed air, which makes a wave on the item normal for chocolate-covered items accessible on the store racks. An appropriately tempered chocolate displays reflexive, proper dissolving temperature and fat-blossom security with wanted trademark crunchiness and hardness during eating, relying upon the measure of chocolate on the result [17].

\subsection{Back Extrusion and Viscoelastic Properties.} Concerning Table 3 , OF $(1.515 \mathrm{~N})$, TF $(10.536 \mathrm{~N})$, and ML $(36.520 \mathrm{~N})$ syrups showed the most reduced protection from the activity of the pivot power. The main trouble in embeddings and broadening the pivot, which was related to the need to apply an immense power, can be seen due to PM $(309.583 \mathrm{~N})$ and GS $(295.730 \mathrm{~N})$. Presumably, the fundamental justification of the distinctions in these boundaries is the consistency of the syrups utilized and the individual parts that are segments of these syrups. For Newtonian liquids (counting water, which is the fundamental segment of all syrups utilized), the consistency does not rely upon the shear rate; however, it relies upon the substance's properties shaping the liquid and its thermodynamic boundaries like temperature and pressing factor. On the other hand, the various carbohydrates present in the syrups (including polyhydric alcohols) mean that these syrups do not behave like Newtonian liquids, which means that they are characterized by different parameters of backward extrusion analysis $[18,19]$.

With regard to Table 3, $\mathrm{G}^{\prime}$ values increase significantly in the case of PM syrup, which testifies the strengthening of the gel structure of high-protein bars made of it $(P<0.05)$. The storage $\left(\mathrm{G}^{\prime}\right)$ modulus values were consistently lower than the loss $\left(\mathrm{G}^{\prime \prime}\right)$ modulus in all tested samples. It means that measured syrups exhibited viscous properties during the whole measurement. A correlation of storage $\left(G^{\prime}\right)$ and loss $\left(G^{\prime \prime}\right)$ with hardness values of high-protein bars was noticed, indicating that the structure of obtained product becomes harder and more compact along with the use of PM syrup to application. When the loss tangent $\delta<45^{\circ}$, the product exhibits elastic (gel) properties; otherwise (i.e., $\delta>45^{\circ}$ ), the product shows viscous properties. In every tested syrup, the value of $\delta$ was higher than $45^{\circ}$, so they can be considered viscous-like products. The PM syrup presented the highest value of measure features, which means that this syrup has greater elastic properties than other tested samples. The highest values of shear stress were also found for this syrup. It is consistent with the conclusions of other researchers who have studied agave syrup used for muffin making [20], high-fructose corn syrup used for high-protein bars production [2], and syrup systems with various viscoelastic properties [21], who showed that the use of different sources of carbohydrates and polyols and their mutual ratio and degree of hydration affect the storage $\left(\mathrm{G}^{\prime}\right)$ and loss $\left(\mathrm{G}^{\prime \prime}\right)$ moduli values. An increase in the water content in syrups probably causes a decrease in their viscosity parameters, thus contributing to increased parameters related to castability properties. It may play an important role, especially in the case of baked products, due to the need to extend the long thermal processes to achieve the textural parameters of the finished products comparable to the commonly used syrups (sugar, glucose, glucose-fructose syrups) [20]. According to other researchers, there is a direct link between the amount of protein and storage values $\left(\mathrm{G}^{\prime}\right)$ and loss $\left(\mathrm{G}^{\prime \prime}\right)$ in high-protein products. It is because with a low sugar content in whey protein concentrates and isolates, when the proteins are denatured, their gelation temperature is shifted [22]. Based on the research performed by Koh et al. [23], it is possible that the development nature of the storage values $\left(\mathrm{G}^{\prime}\right)$ and its thermal stability change as a result of the addition of different levels of cosolvent $(40-70 \%)$ in the formulation of the products. In addition, there is a sharp drop in the storage modulus between 40 and $70 \%$ of the sugar concentration of the polysaccharide used for production. This is the same for all the syrups used in our study, except PM, possibly as a result of the high soluble fiber content.

3.3. Water Activity. The estimation of water activity of high-protein bars is shown in Figure 1. During the storage stage, the water activity of high-protein bars changes [24]. The explanation of this process may be the research carried out earlier by other researchers. It is assumed that high-protein bars have water in two states: bound water and free water. The interaction between free water and the protein surface is usually weak, while bound water shows a strong association with protein and saccharide molecules [25]. Various states of humidity are exchanged between the zones surrounding the surface of protein molecules. During the storage period, the humidity increases by approx. 4\%. The hydrophobicity of different types of proteins when combined with individual syrups can vary considerably. The interaction between bound water and protein is enhanced, which is one of the reasons why highprotein bars harden [26, 27]. Hence, the bars were put away for three weeks in a fixed plastic box (each bar was additionally wrapped in a high-barrier metalized foil) at $20^{\circ} \mathrm{C}$. The stockpiling time was obtained based on Banach et al.'s [28] research, which showed that the aw increase was not significant after this period.

The highest $\mathrm{a}_{\mathrm{w}}$ esteem described a bar without chocolate covering made with chickpea-maize syrup (PM) of 0.802 and the least (GS) of 0.715 high-protein bar made with glucose syrup and chocolate covering. Acknowledged speculations guarantee that most offal microbes will develop down to about $0.95 \mathrm{aw}$, which is the reason microorganisms are the dominant vegetation of most high-moisture food sources. Other bacteria, many of public health concern, may reach values of 0.90 or even $0.85 \mathrm{a}_{\mathrm{w}}$. Except for moderate and high halophilic ones (e.g., those that settle brackish waters and salt-rich food sources), microbes do not contend well in "high osmotic" (low $\mathrm{a}_{\mathrm{w}}$ ) conditions. Accordingly, food items with a water activity underneath 0.85 are moderately microbiological safe [29]. All prepared bars had a water activity beneath 0.85 . Nonetheless, considering the outcomes got on account of a bar made of PM syrup, it tends to be expected that it will show the most elevated helplessness to the improvement of microorganisms specifically forms (mycotoxigenic penicillia), 
TABLE 3: Values of back extrusion force, $G^{\prime}, G^{\prime \prime}$ modulus, and $\delta\left({ }^{\circ}\right)$ of tested syrups used in high-protein bars.

\begin{tabular}{lcccc}
\hline Type of syrup & Force $(\mathrm{N})$ & $\mathrm{G}^{\prime}(\mathrm{Pa})$ & $\mathrm{G}^{\prime \prime}(\mathrm{Pa})$ & $\delta\left(^{\mathrm{o}}\right)$ \\
\hline OF & $1.515^{\mathrm{a}} \pm 0.058$ & $0.104^{\mathrm{a}} \pm 0.102$ & $2.484^{\mathrm{a}} \pm 0.133$ & $90.919^{\mathrm{b}} \pm 3.207$ \\
TF & $10.536^{\mathrm{b}} \pm 0.420$ & $0.801^{\mathrm{a}} \pm 0.141$ & $16.915^{\mathrm{b}} \pm 1.825$ & $90.028^{\mathrm{ab}} \pm 5.330$ \\
ML & $36.520^{\mathrm{c}} \pm 1.219$ & $0.124^{\mathrm{a}} \pm 0.115$ & $2.325^{\mathrm{a}} \pm 0.182$ & $88.472^{\mathrm{a}} \pm 4.094$ \\
PM & $309.583^{\mathrm{e}} \pm 3.247$ & $48.340^{\mathrm{b}} \pm 10.697$ & $158.417^{\mathrm{d}} \pm 23.573$ & $98.582^{\mathrm{c}} \pm 18.856$ \\
GS & $295.730^{\mathrm{d}} \pm 2.993$ & $0.798^{\mathrm{a}} \pm 0.641$ & $32.292^{\mathrm{c}} \pm 1.043$ & $89.390^{\mathrm{ab}} \pm 1.475$ \\
\hline
\end{tabular}

Data are presented as means \pm SD (standard deviation). ${ }^{\text {a-e }}$ Means in the same column with different superscripts are significantly different $(P<0.05$, Tukey's HSD test). OF: oligofructose, TF: tapioca liquid fiber, ML: maltitol, and PM: chickpea-maize liquid fiber.

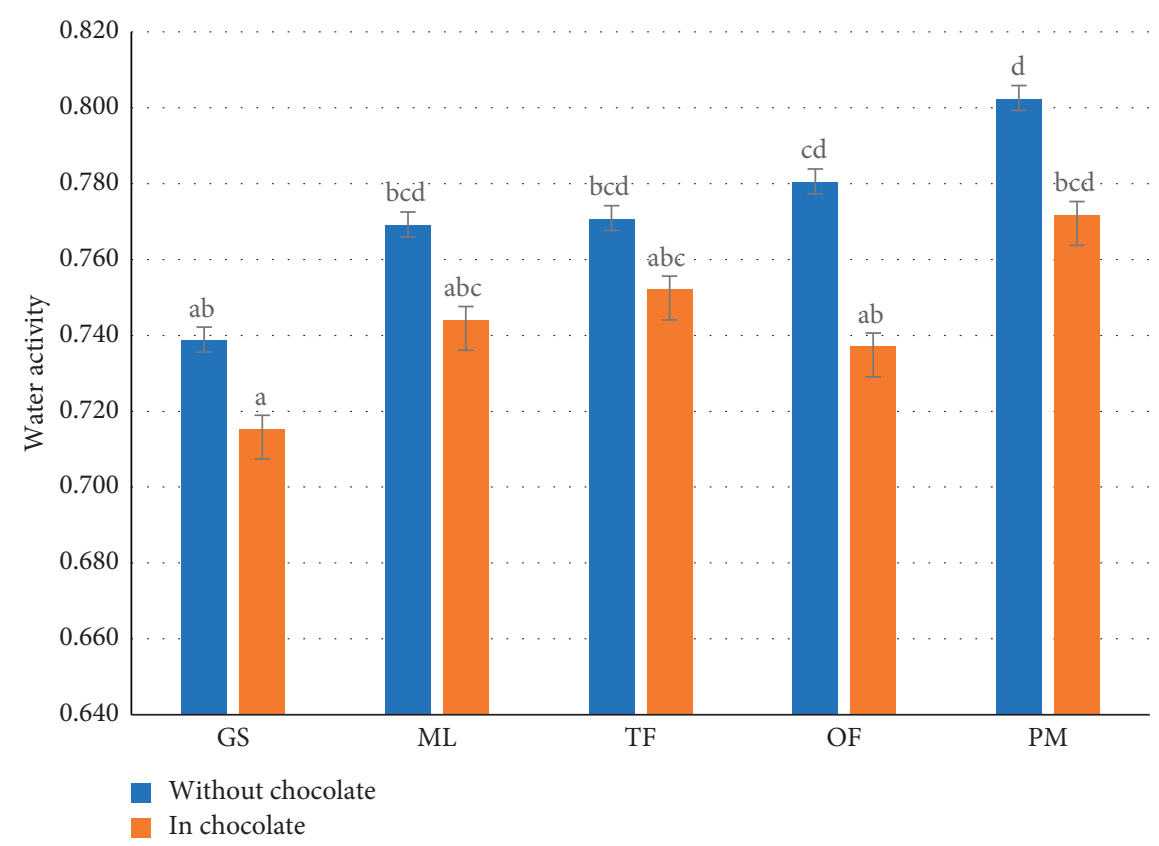

FIGURE 1: Impact of different syrup applications on water activity of high-protein bars without chocolate covering and with chocolate covering. Letters (a-d) indicate significant differences at $P<0.05$ (Tukey's HSD test). OF oligofructose, TF-tapioca liquid fiber, ML-maltitol, PM-chickpea-maize liquid fiber.

Staphylococcus aureus, Saccharomyces (most bailii spp., Debaryomyces) [30]. Such high water activity boundaries on account of this syrup might show a high substance of artificially unbound water in this sort of syrup [31]. Bound water molecules have intense water-ion and possibly hydrogen-ion and water-dipole interactions between the water and protein and sugar/polyol molecules as indicated by the current information on changes in the design or association of syrups in an item might be related to the actual properties of syrups and the protein utilized. Properties, for example, water content, Brix, consistency, and the capacity to emulsify assume a significant role [32]. The distinctions on account of the examples with chocolate covering might result from the limitation of air admittance to the item's inside because of the covering with a layer of chocolate. The high water action worth of bars made of PM syrup might be identified with the high limit of this sort of syrup to assimilate water and fat [33].

3.4. Computer Vision System (CVS) and Determining Color Differences. Usually, the fundamental perspective that lessens the nature of high-protein bars is their solidifying after some time. In any case, visual assessment can likewise be a basic quality pointer for customers of this kind of product. The color of bars made of different kinds of syrups following three weeks of storage is introduced in Tables 4 and 5. The color of a bar made of GS was adopted as the reference sample.

The most habitually utilized strategies for color appraisal in the investigation of food items are colorimetric techniques. In turn, the colors tested using Computer Vision System accurately resemble the actual color of the samples being evaluated. In addition, the color is more intense than for standard colorimetric methods [34]. Inami et al. [35] indicated that all the color contrasts communicated by values more significant than 6 are considerable. Discrepancies $<6$ prove a slight influence of the syrup used on the difference in the color of high-protein bars. In this situation, an eyewitness will notice differences in the color of the product. The shade of the bars made of PM and ML syrups most closely resembled the shade of the control sample made of GS. Considering examination of McMahon et al. [16], the adjustment of the shade of high-protein bars dependent on whey proteins after the 20th day of storage, paying little heed to the kind of syrup utilized, causes a 
TABLE 4: Impact of different syrups on the color of high-protein bars without chocolate covering measured with computer vision system (CVS).

\begin{tabular}{|c|c|c|c|c|c|}
\hline \multirow{2}{*}{ Type of syrup used in bars with chocolate covering } & \multicolumn{5}{|c|}{ Attributes } \\
\hline & $L^{*}$ & $a^{*}$ & $b^{*}$ & $\Delta E$ & NBS units \\
\hline $\mathrm{OF}$ & $58.86^{\mathrm{a}} \pm 0.388$ & $19.71^{\mathrm{a}} \pm 0.488$ & $49.71^{\mathrm{d}} \pm 0.488$ & 22.21 & 20.44 \\
\hline $\mathrm{TF}$ & $60.29^{\mathrm{b}} \pm 0.488$ & $20.29^{\mathrm{a}} \pm 0.756$ & $52.14^{\mathrm{e}} \pm 1.069$ & 23.46 & 21.58 \\
\hline ML & $65.57^{\mathrm{c}} \pm 0.787$ & $15.43^{\mathrm{d}} \pm 0.535$ & $44.57^{\mathrm{c}} \pm 0.787$ & 13.02 & 11.98 \\
\hline PM & $70.00^{\mathrm{d}} \pm 0.000$ & $12.86^{\mathrm{c}} \pm 0.378$ & $40.43^{\mathrm{b}} \pm 0.535$ & 6.77 & 6.23 \\
\hline GS & $72.14^{\mathrm{e}} \pm 0.378$ & $10.57^{\mathrm{b}} \pm 0.535$ & $34.43^{\mathrm{a}} \pm 1.134$ & - & - \\
\hline
\end{tabular}

Data are presented as means $\pm \mathrm{SD}$ (standard deviation). ${ }^{\text {a-e }}$ Means in the same column with different superscripts are significantly different $(P<0.05$, Tukey's HSD test). "- "NBS Units of GS syrup reference sample, not subject to calculation. OF: oligofructose, TF: tapioca liquid fiber, ML: maltitol, and PM: chickpeamaize liquid fiber.

TABLE 5: Recorded differences in the color of the tested high-protein bars based on computer vision system (CVS) photos.

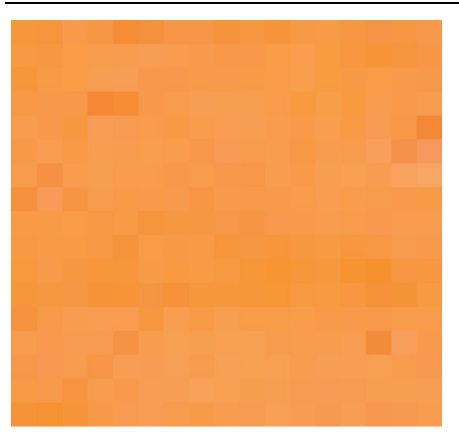

(a)

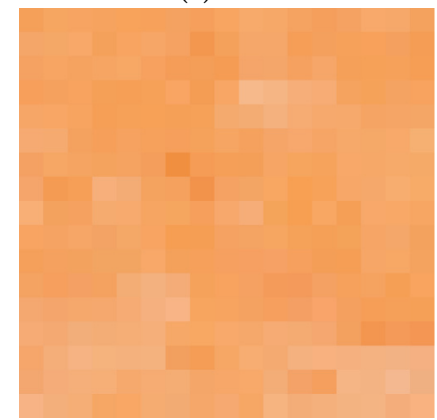

(d)

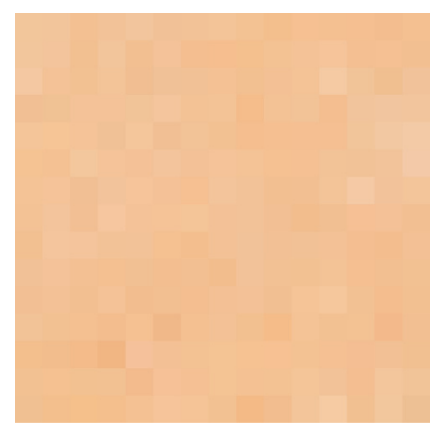

(b)

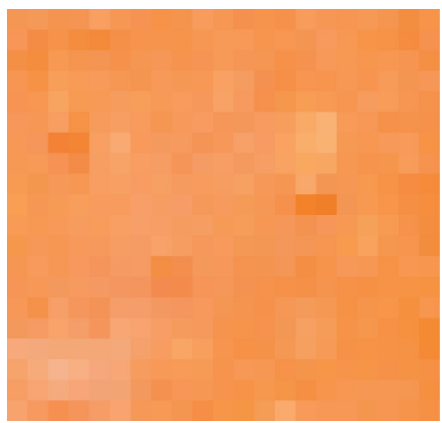

(c)

(e)

perceptible change in the $\mathrm{b}^{*}$ boundary, yellow tone, which becomes brown. The investigations performed additionally affirm McMahon et al.'s [16] research that bars made of whey proteins with glucose syrup over the long haul have a high propensity to darkening. The hue of bars with chocolate covering was not analyzed. Yet, it may be accepted that they would have more splendid hues because of better assurance against light and air access and subsequently hindering the Maillard reaction.

3.5. Ultrasonic Viscosity. Ultrasonic viscometer viscosity estimations were performed at high frequency, and therefore, it is difficult to contrast the acquired outcomes, and those got utilizing different other viscometers. Likewise, ultrasonic viscometers are utilized for ceaseless viscosity estimations under conditions where estimations can be troublesome, and devices like rotational viscometers cannot be adopted [36]. The ultrasonic viscosity is introduced in Figure 2.

The distinctions in the outcomes for the bars tried in this examination were not huge (besides OF syrup); notwithstanding, the most elevated consistency esteems were recorded for bars made with OF and ML syrups and the least for PM and TF. The results of the bars made of GS syrup are hesitant. In the case of bars without chocolate, this sample showed a low viscosity, while in the case of bars in the chocolate covering, it was definitely one of the highest in the measurement. This outcome is presumably impacted by chocolate, which has a higher unique viscosity than the syrup-protein mix utilized in this bar. The decrease in viscosity on account of most chocolate-covered bars (OF, $\mathrm{ML}, \mathrm{TF}$ ) might be identified with the more slow drying out of high-protein bars by restricting air admittance to the center of the bar. Low values of the viscosity parameter, 


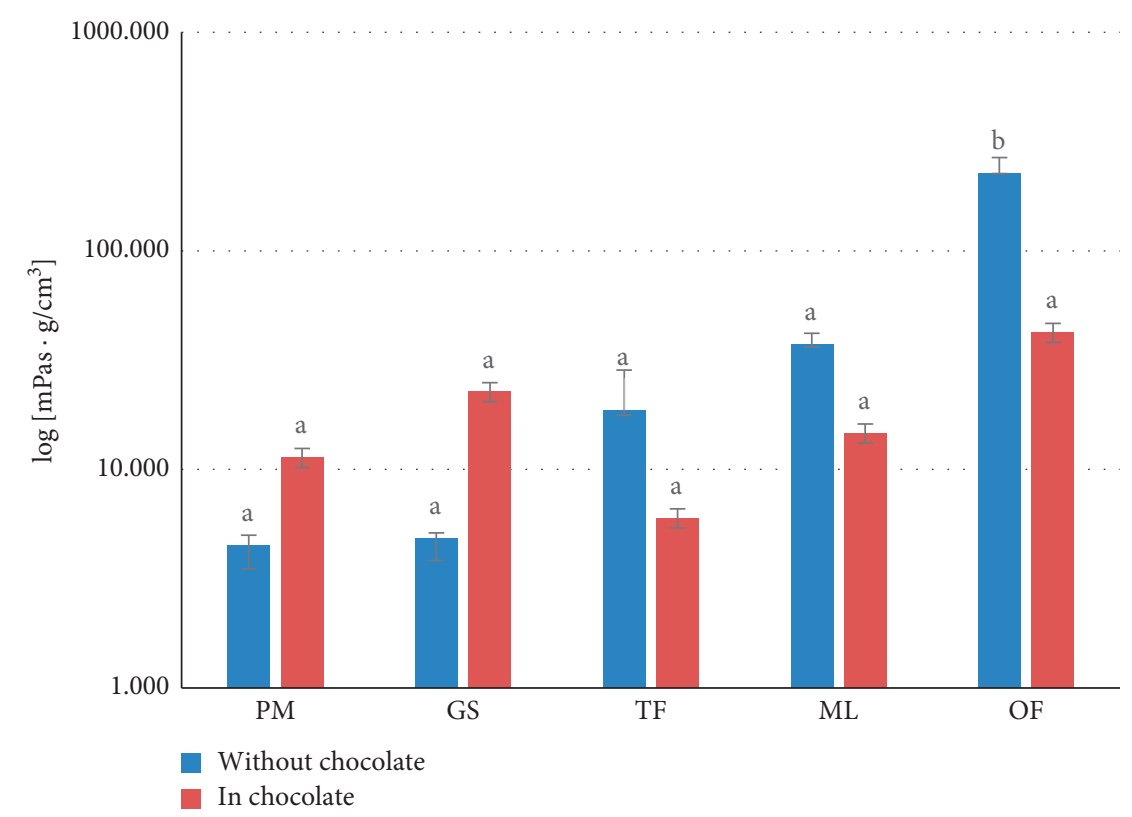

FIGURE 2: Ultrasonic viscosity measurement results $\left(\mathrm{mPas} \mathrm{g} / \mathrm{cm}^{3}\right)$ of tested high-protein bars without chocolate covering and with chocolate covering. Letters (a-b) indicate significant differences at $P<0.05$ (Tukey's HSD test). OF oligofructose, TF-tapioca liquid fiber, ML_maltitol, PM—chickpea-maize liquid fiber.

particularly for PM and GS, correlate with high results of the hardness parameters in bars without chocolate covering and high parameters of $G^{\prime \prime}$ moduli for GS and PM syrups. On the other hand, the relatively high dynamic viscosity of the parameters of the bars made from syrups OF, ML, and TF has been linked to their relatively low hardness and the low parameters of the cutting force. Considering the obtained results and comparing them with the research by Tomczyńska-Mleko et al. [37], it can be assumed that the obtained results could be influenced by factors such as degree of aeration in the bar mass and the consistency and protein concentration the product was made of. Moreover, research conducted by Małecki et al. [4] concerned the use of various types of proteins in high-protein bars and confirmed the dependence that low values of the product viscosity parameter correlate with high hardness parameters. In addition, it is not easy to find other publications to compare the results obtained in this study because the ultrasonic viscosity tests are a rare/novel method for analyzing food items.

3.6. Nutritional Value. Nutritional data and health benefits on the packaging of all food items are obligatory and normalized by pertinent EU guidelines, chiefly by Regulation (EU) No $1169 / 2011$ of the European Parliament and of the Council of 25 October 2011 on the provision of food information to consumers [38]. For the present purchasers who pick proteinadvanced items, one of the urgent things is a dietary benefit. The aftereffects of the tried bars' energy and sustenance esteem introduced in Figures 3(a), 3(b), 4(a), and 4(b) show a contrast between the bars made of different syrups.

The main deviation can be found in the higher energy worth and fiber content for bars made of GS syrup. Bars made of TF and PM syrup had the most reduced energy esteem. It was additionally connected with the most significant levels of fiber when these syrups were utilized. It is essential that the utilization of TF, OF, and PM syrups brought about high-fiber content in completed items (>6\%). This measure of fiber allows the nutrition claim "high-fiber content" to be used on the packaging of these products following Regulation (EC) No 1924/2006 of The European Parliament and of The Council of 20 December 2006 [39] on nutrition and health claims made on foods. It is essential because observational examinations have shown that dietary fiber admission is related to diminished danger of cardiovascular sickness. Dietary fiber is a nonedible type of sugars because of the absence of enzymes in the human digestive system needed to process this component. The recommended daily allowances (RDAs) for total fiber intake for men and women aged 19-50 are $38 \mathrm{~g} /$ day and $25 \mathrm{~g} /$ day, respectively [6]. Analyzing the work of researchers [40], in which high-protein bars were analyzed as substitutes for meals for athletes, with a mixture of glycerol, maltodextrin, and inulin as a sticking agent, it can be assumed that the bars obtained in this study also fit this trend, and in the case of TF, OF syrups and PM products contain significant amounts of fiber and the product does not require any warning information to be placed on the packaging against a possible laxative effect. In accordance with the applicable EU law, the use of polyhydric alcohols in the amount greater than $10 \%$ requires such a declaration [41]. Based on Figures 4(a) and 4(b), it can be observed that the measured high-protein bars had a low content of saturated fats. It is a crucial feature of food, especially for actively practicing sports and being physically active. Saturated and trans fatty acids are considered to be the most harmful to health types of fatty acids. Their high consumption is conducive to the development of, among others, risk of cardiovascular disease and type 2 diabetes [42]. 


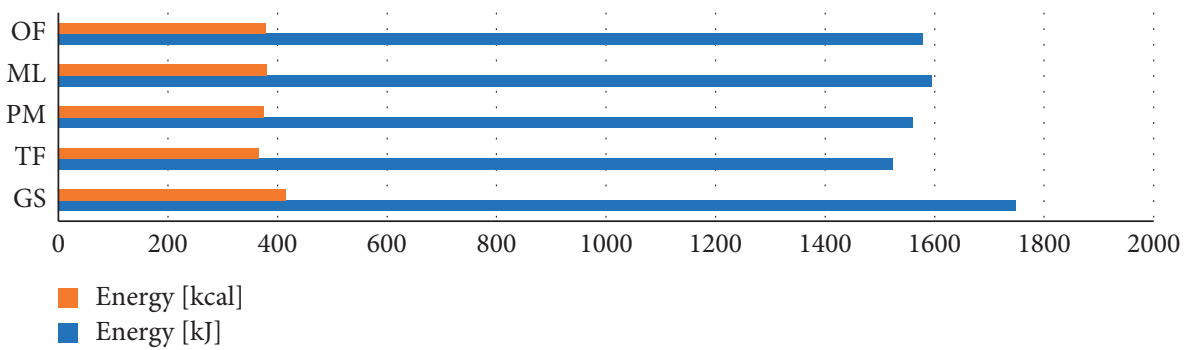

(a)

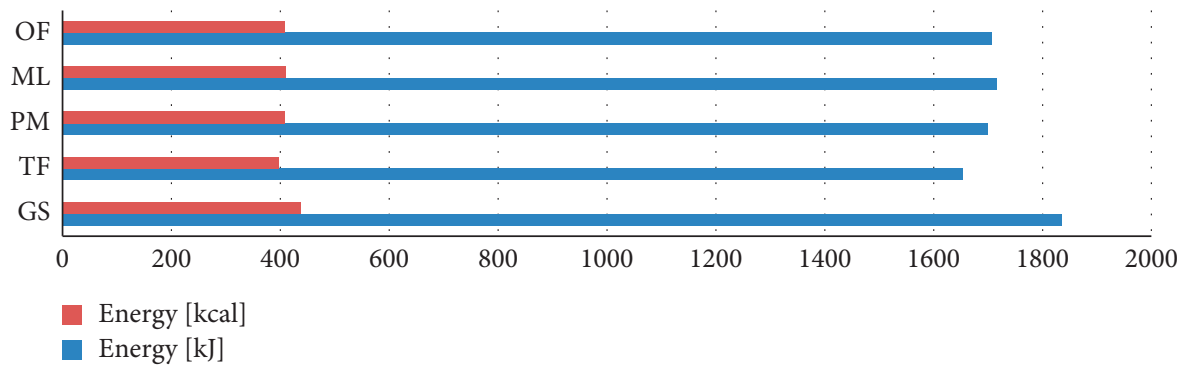

(b)

Figure 3: (a) Energy value of high-protein bars without chocolate covering; (b) with chocolate covering. OF oligofructose, TF-tapioca liquid fiber, ML—maltitol, PM—chickpea-maize liquid fiber.

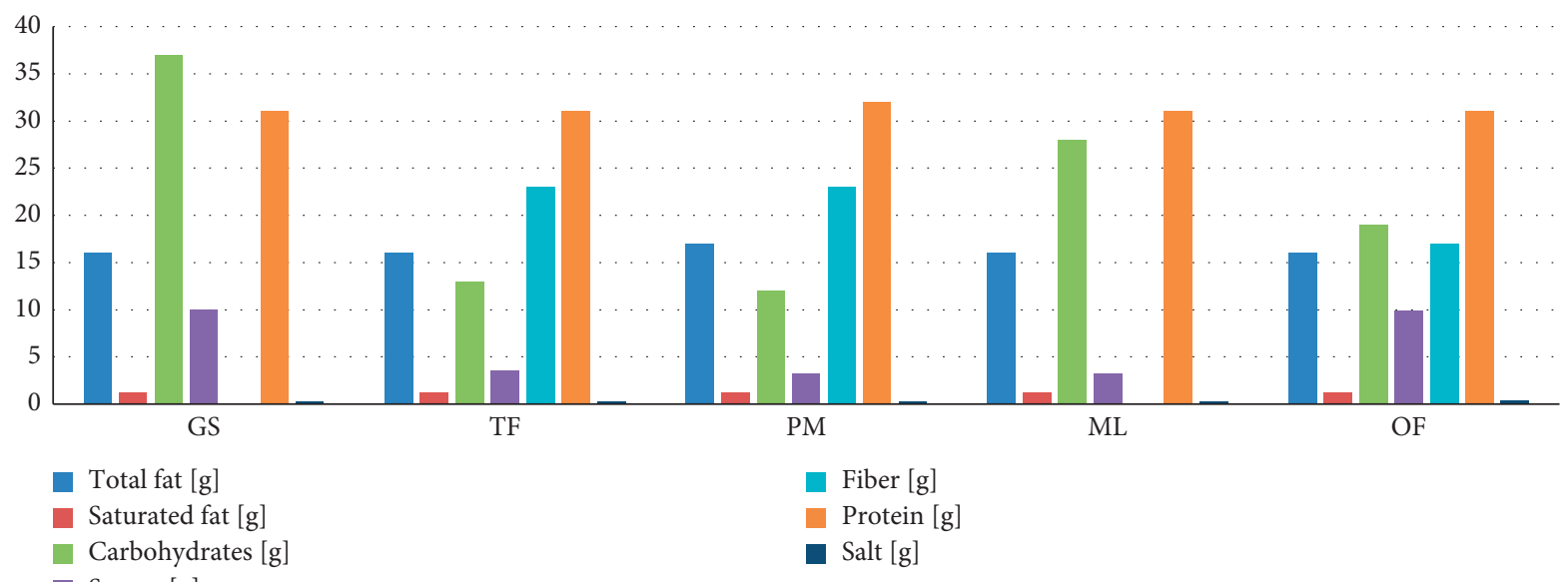

(a)

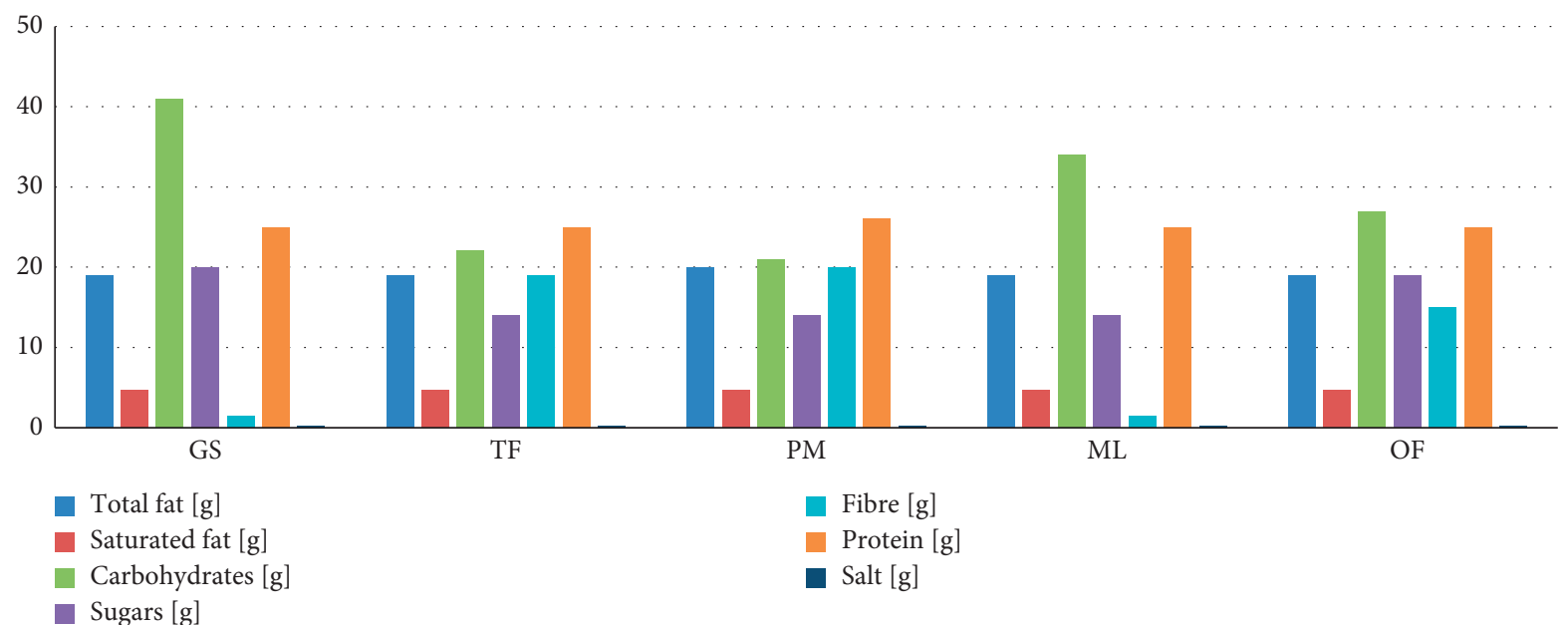

(b)

FIGURE 4: (a) Nutritional value of high-protein bars without chocolate covering; (b) with chocolate covering. OF oligofructose, TF-tapioca liquid fiber, ML—maltitol, PM—chickpea-maize liquid fiber. 


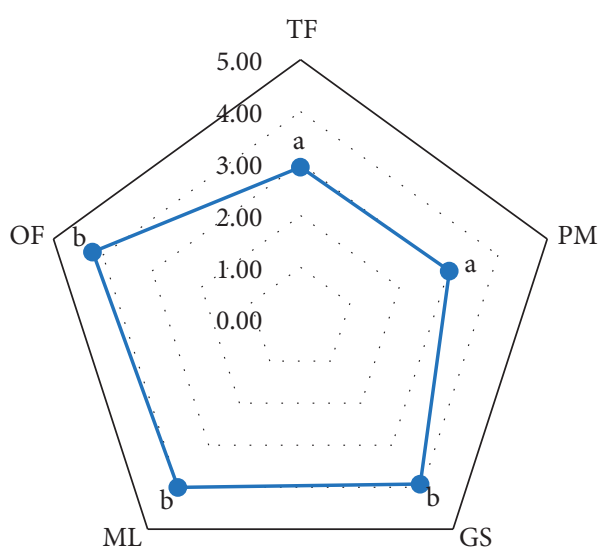

(a)

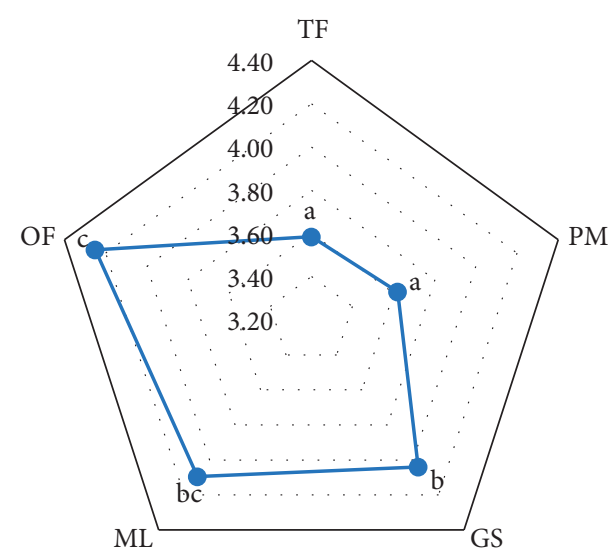

(b)

FIGURE 5: (a) Sensory evaluation of high-protein bars without chocolate covering; (b) with chocolate covering. Means in the same point with different superscripts $\left({ }^{\mathrm{a}-\mathrm{c}}\right)$ are significantly different $(P<0.05$, Tukey's HSD test). OF oligofructose, TF-tapioca liquid fiber, ML-maltitol, PM-chickpea-maize liquid fiber.

3.7. Sensory Evaluation. Aftereffects of the sensory evaluation of the tested high-protein bars are introduced in Figures 5(a) and 5(b). The most elevated scores were got for bars made with OF, ML, and GS syrups. The evaluators most liked the outside appearance, surface, and taste impressions of the bars. Sensory studies conducted by other researchers $[40,43]$ also indicate that color, textural parameters (primarily hardness and chewiness), aftertaste (mainly bitter), and not-specific smell may exert the greatest influence on the assessments of people participating in the study. Consumers prefer sweet flavors with a balanced, easy-to-chew texture [43].

The most exceedingly terrible appraised bars (TF and PM) had too high chomp hardness and an indistinct unsavory lingering flavor, which gave them the most minor evaluations. It might presumably be identified with the extremely high-fiber content of these kinds of syrups used in bars. However, tapioca, which is a good source of vitamin C, calcium, phosphorus, and probiotics, can improve digestion and boost the immune system in humans. Based on the available knowledge, this type of fiber can also be used to lower the percentage of fat in food products [44, 45]. Acquired outcomes propose that high-protein bars with chocolate covering significantly upgrade their agreeability. Obtained results suggest that high-protein chocolate covering greatly enhances their palatability. Referring to the research conducted by other researchers, which concerned research on the use of polyols in shaping the physicochemical properties of soybean isolates, the high ratings of the bar made of ML syrup may be related to the influence of polyols on the structural and surface properties. The interaction of proteins with polyols induces an increased structural order and concentration of protein molecules [5].

\section{Conclusions}

Based on the sophistication, it can be concluded that changes in the texture and rheology, as well as color, and nutritional and sensorial properties significantly depend on the type of syrup used in the study. The lowest results characterized bars made with OF, TF, and ML syrups during the TPA test and evaluation of viscoelastic properties $\left(G^{\prime}, G^{\prime \prime}\right.$ moduli) and provide similar parameters of water activity as when using standard glucose syrup (GS). It may indicate the use of these syrups may potentially result in lower hardness of the finished products related to the control sample. Bars made with OF syrup were characterized by the lowest parameters in TPA determinations, which also translated into high parameters of the sensory evaluation of this type of bars. All the glucose syrup equivalents used, except for ML syrup, enable the declaration of "high-fiber content" on the product packaging based on EU standards. It is worth noting that the product made of PM syrup had the highest fiber content (20\%), which may be especially valid for people interested in a high-fiber diet. Based on the color assessment using the CVS method and sensory analysis of bars without chocolate covering, it can be concluded that color plays a relevant role for consumers. Sensory analysis showed that the covering of high-protein chocolate bars raises assessment of the tested products, essentially masking certain smells, colors, and tastes of some kinds of syrups, thus helping to increase the overall sensory evaluation. Therefore, it can be unequivocally suggested that high-protein bars should be covered with chocolate. Taking into account the obtained results, however, it can be assumed that such syrup as OF, TF, or ML may be an attractive alternative to GS in high-protein products. More research is needed into storage tests and to investigate the impact of changes in other ingredients in the recipe that may affect parameters necessary for products in the food industry.

\section{Data Availability}

The data used to support the findings will be available from the corresponding author upon request.

\section{Conflicts of Interest}

The authors declare that there are no conflicts of interest regarding the publication of this paper. 


\section{Authors' Contributions}

B.G.S. and J.M. conceptualized the study, acquired funding, and provided resources. B.G.S., I.T. were responsible for methodology; provided software; and supervised and validated the study. J.M. was responsible for formal analysis and investigation. J.M. was responsible for data curation, original draft preparation, and visualization. B.G.S. reviewed and edited the manuscript and responsible for project administration. All authors have read and agreed to the published version of the manuscript.

\section{Acknowledgments}

This research was financially supported by EUROHANSA Sp. z o. o. The authors thank Bożena Czogała-President of EUROHANSA $\mathrm{Sp} . \mathrm{z}$ o. o.-for providing machines and equipment for the production of high-protein bars and to all suppliers for providing raw materials. The authors would like to thank Ilija Djekic from the Department of Management of Food Safety and Quality, Faculty of Agriculture, University of Belgrade, Serbia, for his help with the computer vision system method. This work was financially supported by the Ministry of Science and Higher Education grant in Poland (grant number 0029/DW/2018 "Implementation doctorate").

\section{References}

[1] M. Henchion, M. Hayes, A. Mullen, M. Fenelon, and B. Tiwari, "Future protein supply and demand: strategies and factors influencing a sustainable equilibrium," Foods, vol. 6, no. 7, pp. 53-21, 2017.

[2] K. Sparkman and H. S. Joyner, "Impact of formulation on high-protein bar rheological and wear behaviors," Journal of Texture Studies, vol. 50, no. 6, pp. 445-455, 2019.

[3] S. R. Imtiaz, B. Kuhn-Sherlock, and M. Campbell, "EFfect of dairy protein blends on texture of high protein bars," Journal of Texture Studies, vol. 43, no. 4, pp. 275-286, 2012.

[4] J. Małecki, I. Tomasevic, I. Djekic, and B. G. Sołowiej, "The effect of protein source on the physicochemical, nutritional properties and microstructure of high-protein bars intended for physically active people," Foods, vol. 9, no. 10, p. 1467, 2020.

[5] P. Mingzhe, M. Xianjun, J. Lianzhou, Y. Dianyu, and L. Tianyi, "Effect of cosolvents (polyols) on structural and foaming properties of soy protein isolate," Czech Journal of Food Sciences, vol. 35, no. 1, pp. 57-66, 2017.

[6] G. A. Soliman, "Dietary fiber, atherosclerosis, and cardiovascular disease," Nutrients, vol. 11, no. 5, p. 1155, 2019.

[7] S. A. Hogan, I. B. O'Loughlin, and P. M. Kelly, "Soft matter characterisation of whey protein powder systems," International Dairy Journal, vol. 52, pp. 1-9, 2016.

[8] J. O. Szafrańska, S. Muszyński, and B. G. Sołowiej, "Effect of whey protein concentrate on physicochemical properties of acid casein processed cheese sauces obtained with coconut oil or anhydrous milk fat," LWT-Food Science and Technology, vol. 127, Article ID 109434, 2020.

[9] I. Tomasevic, V. Tomovic, B. Milovanovic et al., "Comparison of a computer vision system vs. traditional colorimeter for color evaluation of meat products with various physical properties," Meat Science, vol. 148, pp. 5-12, 2019.
[10] B. Milovanovic, I. Djekic, V. Djordjevic et al., "Pros and cons of using a computer vision system for color evaluation of meat and meat products," IOP Conference Series: Earth and Environmental Science, vol. 333, no. 1, Article ID 012008, 2019.

[11] S. A. Hogan, V. Chaurin, B. T. O’Kennedy, and P. M. Kelly, "Influence of dairy proteins on textural changes in highprotein bars," International Dairy Journal, vol. 26, no. 1, pp. 58-65, 2012.

[12] E. Ermiş and E. N. Karasu, "Püskürtmeli kurutucu Ile Yaği alinmiş Ayçiçeği Protein ekstrakti tozu Üretimi: fonksiyonel Özellikleri ve toz Karakterizasyonu," Gida/Journal of Foodservice, vol. 45, pp. 39-49, 2020.

[13] A. Pihlanto, P. Mattila, S. Mäkinen, and A.-M. Pajari, "Bioactivities of alternative protein sources and their potential health benefits," Food \& Function, vol. 8, no. 10, pp. 3443-3458, 2017.

[14] S. M. Loveday, J. P. Hindmarsh, L. K. Creamer, and H. Singh, "Physicochemical changes in a model protein bar during storage," Food Research International, vol. 42, no. 7, pp. 798-806, 2009.

[15] Y. Li, K. Szlachetka, P. Chen, X. Lin, and R. Ruan, "Ingredient characterization and hardening of high-protein food bars: an NMR state diagram approach," Cereal Chemistry Journal, vol. 85, no. 6, pp. 780-786, 2008.

[16] D. J. McMahon, S. L. Adams, and W. R. Mcmanus, "Hardening of high-protein nutrition bars and sugar/polyol-protein phase separation," Journal of Food Science, vol. 74, no. 6, pp. E312-E321, 2009.

[17] F. Debaste, Y. Kegelaers, S. Liégeois, H. B. Amor, and V. Halloin, "Contribution to the modelling of chocolate tempering process," Journal of Food Engineering, vol. 88, no. 4, pp. $568-575,2008$.

[18] T. Hoshino, K. Kawai, and Y. Hagura, "Proposal of short back extrusion method for enabling consecutive viscosity measurements of high-viscosity Newtonian fluid," Nippon Shokuhin Kagaku Kogaku Kaishi, vol. 60, no. 2, pp. 100-109, 2013.

[19] C. M. Ionescu, I. R. Birs, D. Copot, C. I. Muresan, and R. Caponetto, "Mathematical modelling with experimental validation of viscoelastic properties in non-Newtonian fluids," Philosophical Transactions of the Royal Society A: Mathematical, Physical \& Engineering Sciences, vol. 378, no. 2172, pp. 20190284-20190321, 2020.

[20] C. Ozuna, E. Trueba-Vázquez, G. Moraga, E. Llorca, and I. Hernando, "Agave syrup as an alternative to sucrose in muffins: impacts on rheological, microstructural, physical, and sensorial properties," Foods, vol. 9, no. 7, pp. 895-915, 2020.

[21] R. Wang and R. W. Hartel, "Effects of moisture content and saccharide distribution on the stickiness of syrups," Journal of Food Engineering, vol. 284, pp. 110067-110081, 2020.

[22] K. Kusio, J. O. Szafrańska, W. Radzki, and B. G. Sołowiej, "Effect of whey protein concentrate on physicochemical, sensory and antioxidative properties of high-protein fat-free dairy desserts," Applied Sciences, vol. 10, no. 20, p. 7064, 2020.

[23] L. Koh, B. Jiang, S. Kasapis, and C. W. Foo, "Structure, sensory and nutritional aspects of soluble-fibre inclusion in processed food products," Food Hydrocolloids, vol. 25, no. 2, pp. 159-164, 2011.

[24] J. C. Banach, S. Clark, and B. P. Lamsal, "Texture and other changes during storage in model high-protein nutrition bars formulated with modified milk protein concentrates," Lebensmittel-Wissenschaft und -Technologie- Food Science and Technology, vol. 56, no. 1, pp. 77-86, 2014. 
[25] D. J. McClements, "Modulation of globular protein functionality by weakly interacting cosolvents," Critical Reviews in Food Science and Nutrition, vol. 42, no. 5, pp. 417-471, 2002.

[26] P. Zhou, X. Liu, and T. P. Labuza, "Moisture-induced aggregation of whey proteins in a protein/buffer model system," Journal of Agricultural and Food Chemistry, vol. 56, no. 6, pp. 2048-2054, 2008.

[27] J. Li, Y. Wu, Y. Ma, N. Lu, J. M. Regenstein, and P. Zhou, "Effects of addition of hydrocolloids on the textural and structural properties of high-protein intermediate moisture food model systems containing sodium caseinate," Food \& Function, vol. 8, no. 8, pp. 2897-2904, 2017.

[28] J. C. Banach, S. Clark, and B. P. Lamsal, "Instrumental and sensory texture attributes of high-protein nutrition bars formulated with extruded milk protein concentrate," Journal of Food Science, vol. 81, no. 5, pp. S1254-S1262, 2016.

[29] M. S. Tapia, S. M. Alzamora, and J. Chirife, "Effects of water activity (a w) on microbial stability as a hurdle in food preservation," Water Activity in Foods, vol. 14, pp. 323-355, 2020.

[30] A. Schiraldi, D. Fessas, and M. Signorelli, "Water activity in biological systems-a review," Polish Journal of Food and Nutrition Sciences, vol. 62, no. 1, pp. 5-13, 2012.

[31] "Thermal processing of food," Safefood Whitepaper, vol. 1, pp. 1-8, 2014.

[32] L. Ninni, M. S. Camargo, and A. J. A. Meirelles, "Water activity in polyol systems," Journal of Chemical \& Engineering Data, vol. 45, no. 4, pp. 654-660, 2000.

[33] W. Chanasattru, E. A. Decker, and D. Julian McClements, "Impact of cosolvents (polyols) on globular protein functionality: ultrasonic velocity, density, surface tension and solubility study," Food Hydrocolloids, vol. 22, no. 8, pp. 1475-1484, 2008.

[34] I. Tomasevic, V. Tomovic, P. Ikonic et al., "Evaluation of poultry meat colour using computer vision system and colourimeter," British Food Journal, vol. 121, no. 5, pp. 1078-1087, 2019.

[35] T. Inami, Y. Tanimoto, N. Minami, M. Yamaguchi, and K. Kasai, "Color stability of laboratory glass-fiber-reinforced plastics for esthetic orthodontic wires," The Korean Journal of Orthodontics, vol. 45, no. 3, p. 130, 2015.

[36] A. G. A. Sá, Y. M. F. Moreno, and B. A. M. Carciofi, "Plant proteins as high-quality nutritional source for human diet," Trends in Food Science \& Technology, vol. 97, pp. 170-184, 2020.

[37] M. Tomczyńska-Mleko and L. Ozimek, "Ultrasound viscosity measurements allow determination of gas volume fraction in foamed gels," Journal of Food Process Engineering, vol. 36, no. 5, pp. 572-578, 2013.

[38] A. Fransvea, G. Celano, C. N. Pagliarone et al., "Food labelling: a brief analysis of European Regulation 1169/2011," Italian Journal of Food Safety, vol. 3, no. 3, p. 3, 2014.

[39] J. Borrell Fontelles and J. Korkeaoja, "The european parliment and the council of the european union regulation (EC) No 1924/2006," Official Journal of the European Union, no. 404, pp. 1-17, 2011.

[40] P. Jovanov, M. Sakač, M. Jurdana et al., "High-protein bar as a meal replacement in elite sports nutrition: a pilot study," Foods, vol. 10, no. 11, pp. 2628-2712, 2021.

[41] M. Carocho, P. Morales, and I. C. F. R. Ferreira, "Sweeteners as food additives in the XXI century: a review of what is known, and what is to come," Food and Chemical Toxicology, vol. 107, pp. 302-317, 2017.

[42] A. Astrup, F. Magkos, D. M. Bier et al., "Saturated fats and health: a reassessment and proposal for food-based recommendations," Journal of the American College of Cardiology, vol. 76, no. 7, pp. 844-857, 2020.

[43] V. R. A. Pinto, T. B. d. O. Freitas, M. I. d. S. Dantas et al., "Influence of package and health-related claims on perception and sensory acceptability of snack bars," Food Research International, vol. 101, pp. 103-113, 2017.

[44] F. J. San José, M. Collado-Fernández, and R. López, "Sensory evaluation of biscuits enriched with artichoke fiber-rich powders (Cynara scolymus L.)," Food Sciences and Nutrition, vol. 6, no. 1, pp. 160-167, 2018.

[45] G. Yadav, J. David, S. Thakur et al., "Evaluation of sensory attributes in different levels of Tapioca in pro-biotic Ice cream," The Pharma Innovation, vol. 9, no. 1, pp. 404-407, 2020. 